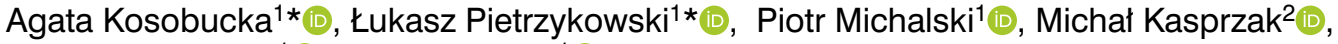

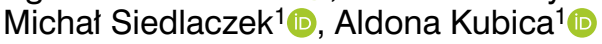

${ }^{1}$ Department of Health Promotion, Collegium Medicum, Nicolaus Copernicus University, Bydgoszcz, Poland

${ }^{2}$ Department of Cardiology and Internal Diseases, Collegium Medicum, Nicolaus Copernicus University, Bydgoszcz, Poland

\title{
Impact of readiness for discharge from the hospital on the implementation of the therapeutic plan
}

\author{
Corresponding author: \\ Agata Kosobucka \\ Department of Health Promotion, \\ Nicolaus Copernicus University, \\ Collegium Medicum, \\ M. Skłodowiskiej-Curie 9 Str. \\ 86-094 Bydgoszcz, Poland, \\ e-mail: akosobucka@wp.pl
}

Medical Research Journal 2020; Volume 5, Number 4, 256-264 10.5603/MRJ.a2020.0047

Copyright (C) 2020 Via Medica ISSN 2451-2591

\begin{abstract}
Introduction. Adherence to therapeutic recommendations regarding pharmacotherapy and lifestyle modification reduces the risk of complications in patients after myocardial infarction. The assessment of readiness for discharge allows to get knowledge about patient's preparation for functioning at home. The aim of the study is to assess the relationship between the readiness for discharge of patients after myocardial infarction and adherence to pharmacotherapy based of the analysis of prescription filling.

Material and methods. The study is a single-center, prospective, observational cohort clinical trial with a one-year follow-up period. The study population include 225 patients ( $26.7 \%$ women and $73.3 \%$ men) aged 30-91years (62.9 \pm 11.9). The RHD-MIS (Readiness for Hospital Discharge after Myocardial Infarction Scale) was used to assess the readiness for discharge. Adherence to medication has been studied in relation to ACE inhibitors, P2Y12 receptor inhibitors and statins.

Results. Patients with a high overall RHD MIS score compared to those with an average result were more likely to have any breaks in therapy, $p=0.01$ (breaks $<30$ days, $p=0.03$ and breaks $\geq 30$ days, $p=0.005)$ for either drug. Patients declaring that their disease is not serious have significantly lower adherence to P2Y12 receptor inhibitor $(28 \pm 27 \%$ vs $72 \pm 38 \%, p=0.047)$ and statins $(36 \pm 41 \%$ vs $76 \pm 33 \% p=0.024)$ in the $1^{\text {st }}$ quarter after discharge and to statins $\quad(23 \pm 18 \%$ vs $65 \pm 32 \%$ $\mathrm{p}=0.014$ ) during whole one-year follow-up.

Conclusion. The readiness for discharge from the hospital assessed with the RHD-MIS does not clearly affect the implementation of the therapeutic plan in the long-term follow-up in patients after myocardial infarction. Data suggesting a negative impact of some aspects of readiness for discharge on adherence to treatment require further, in-depth research.

Key words: readiness for discharge from the hospital, myocardial infarction, adherence to treatment
\end{abstract}

Med Res J 2020; 5 (4): 256-264

\section{Introduction}

Cardiovascular diseases are still one of the leading causes of death [1,2]. The implementation of the therapeutic plan regarding pharmacotherapy and lifestyle modification in patients after myocardial infarction reduces risk of death, reinfarction and stroke [3-5].

A meta-analysis of twenty studies by Naderii et al. showed that adherence to pharmacotherapy in patients with chronic coronary disease varies between 50 and $66 \%$ [6]. To improve adherence in patients after myocardial infarction, understanding of the nature of disease and applied therapy is necessary.
Education of patients and preparation for functioning at home is a standard procedure during hospitalization for acute coronary syndrome [7-9]. To evaluate the effectiveness of these interventions assessment of the readiness for discharge is necessary [10]. To our best knowledge, the impact of readiness for discharge on the level and dynamics of changes in patient adherence to therapeutic plan after myocardial infarction has not been studied so far.

The aim of the study is to assess the relationship between the readiness for discharge of patients after myocardial infarction and adherence to pharmacotherapy based of the analysis of prescription filling.

*Both authors equally contributed and should be recognized as first authors. 


\section{Material and methods}

The study was planned in accordance with the principles of ethics contained in the Helsinki Declaration and carried out on the basis of the consent of the Bioethics Committee of the L. Rydygier Collegium Medicum in Bydgoszcz, Nicolaus Copernicus University in Torun, No. KB 312/2015 of April 21, 2015. The study is a single-center, prospective, observational, cohort clinical trial with a one-year follow-up period. The presented data were collected as a part of the research project "Impact of educational intervention on adherence to therapeutic recommendations". Some results of this project have already been published [11-14].

The observation included patients admitted to the Department of Cardiology and Internal Diseases, Jurasz University Hospital in Bydgoszcz, between May 2015 and July 2016 due to acute myocardial infarction treated with percutaneous coronary intervention $(\mathrm{PCl})$.

The following inclusion criteria were applied: age $>18$ years, pharmacotherapy consisting of: ACEI (ramipril or perindopril), P2Y12 receptor inhibitor (clopidogrel) and statins (atorvastatin or simvastatin or rosuvastatin). The exclusion criteria were defined as: contraindications to any of the analysed medications (ACEI, P2Y12 receptor inhibitor or statin), presence of comorbidities forcing temporary or permanent discontinuation of any of the analysed medications, predicted lifespan of less than one year, impaired contact with the patient precluding their active participation in educational interventions. All study participants gave their informed written consent before study enrolment.

All study participants received in-hospital educational interventions on ischemic heart disease, focusing on its symptoms and management including recommended lifestyle modifications and the principles of pharmacotherapy. The readiness for discharge from the hospital was assessed using a validated questionnaire Readiness for Hospital Discharge after Myocardial Infarction Scale (RHD-MIS) [15].The RHDS-MIS consists of 23 questions included in three subscales assessing subjective (assessed by the patient) and objective (assessed by medical personnel) knowledge about the disease and patient expectations. Additionally, the questionnaire contains non-scored questions regarding the patient's opinion on the readiness for discharge. The patient can answer each of the questions: a- yes, b- I think yes c- I don't know d- no. For each given answer, the respondent receives from 0 to 3 points. The maximum overall score is 69 points (21 points for subjective, 21 for objective knowledge, and 27 points for patient expectation). Depending on the obtained result, the level of readiness for discharge is defined as low, medium or high, both in terms of the overall result and individual subscales. Patient opinions are a non-scored part of the RHD MIS questionnaire, but may be helpful in planning care and the extent of educational intervention required. The patient can answer "yes", "probably yes", "no" and "not sure" to each of the questions.

Adherence, defined as the availability of prescribed drugs, was assessed on the basis of prescription filling data provided by the National Health Fund (NHF) for reimbursed drugs. Medications non-reimbursed by the NHF (e.g. beta blockers) were not included into the analysis.

The relationship between the results of the RHD MIS and adherence to medication was searched. The adherence $<80 \%$ were considered an insufficient level of implementation of the therapeutic plan, while $\geq 80 \%$ as satisfactory $[16,17]$. Based on one-year follow-up, the analysis was performed for each drug group separately and for all three groups together. In order to assess the variability of adherence, the observation period was divided into quarters (Q1, Q2, Q3, Q4).

\section{Study population}

The study population comprise 225 patients $(26.7 \%$ women and $73.3 \%$ men) aged $30-91$ years $(62.9 \pm 11.9)$. Due to incomplete data regarding study medications (lack of data regarding non-reimbursed drugs), the final analysis comprised 210 patients $(93.3 \%$ of all study participants) receiving ACEI, 194 (86.2\%) treated with a P2Y12 receptor inhibitor, and $222(98.7 \%)$ patients on statin. Due to these limitations, a complete analysis for all three groups of study medication was carried out in 180 patients (80.0\% of study participants). Shortening of follow-up due to patient death (8 cases-3.6\% of the study population) was taken into account during results evaluation. The characteristics of the study group are presented in Table 1.

\section{Statistical analysis}

The statistical analysis was carried out using the Statistica 13.0 package (TIBCO Software Inc, California, USA). Continuous variables were presented as means with standard deviations. The Shapiro-Wilk test demonstrated non-normal distribution of the investigated continuous variables. Therefore, non-parametric tests were used for statistical analysis. Comparisons between two groups were performed with the Mann-Whitney unpaired rank sum test. For comparisons between three or more groups, the Kruskal-Wallis one-way analysis of variance was used. Categorical variables were expressed as the number and the percentage. Categorical variables were compared using the $\chi 2$ test. Results were considered significant at $p<0.05$. 
Table 1. Characteristics of the study group

\begin{tabular}{|c|c|c|c|}
\hline \multirow[t]{2}{*}{ Parameter } & \multirow[t]{2}{*}{ Variable } & \multicolumn{2}{|c|}{ Total sample } \\
\hline & & $\mathbf{n}$ & $\%$ \\
\hline \multirow[t]{2}{*}{ Gender } & Female & 60 & 26.7 \\
\hline & Male & 165 & 73.3 \\
\hline \multirow[t]{2}{*}{ Age } & $<65$ & 129 & 57.3 \\
\hline & $\geq 65$ & 96 & 42.7 \\
\hline \multirow[t]{4}{*}{ Employment status } & Employed & 93 & 41.3 \\
\hline & Unemployed & 13 & 5.8 \\
\hline & Old age pensioner & 91 & 40.4 \\
\hline & Disability Living Allowance recipient & 28 & 12.4 \\
\hline \multirow[t]{4}{*}{ Education } & Primary & 30 & 13.3 \\
\hline & Vocational & 83 & 36.9 \\
\hline & Secondary & 82 & 36.4 \\
\hline & Higher & 30 & 13.3 \\
\hline \multirow[t]{4}{*}{ Economic status } & Very good & 14 & 6.2 \\
\hline & Satisfactory & 199 & 88.4 \\
\hline & Bad & 12 & 5.3 \\
\hline & Very bad & 0 & 0 \\
\hline \multirow[t]{3}{*}{ Marital status } & Unmarried & 25 & 11.1 \\
\hline & Widowed & 33 & 14.7 \\
\hline & Married & 167 & 74.2 \\
\hline \multirow[t]{3}{*}{ Place of residence* } & City & 117 & 52,0 \\
\hline & Town & 44 & 19,6 \\
\hline & The country & 64 & 28.4 \\
\hline \multirow[t]{2}{*}{ History of CAD } & Yes & 102 & 45.3 \\
\hline & No & 123 & 54.7 \\
\hline \multirow[t]{2}{*}{ Prior MI } & Yes & 64 & 28.4 \\
\hline & No & 161 & 71.6 \\
\hline \multirow[t]{2}{*}{ Prior PTCA } & Yes & 82 & 36.4 \\
\hline & No & 143 & 63.6 \\
\hline \multirow[t]{2}{*}{ Prior CABG } & Yes & 34 & 15.1 \\
\hline & No & 191 & 84.9 \\
\hline \multirow[t]{2}{*}{ Hyperlipidaemia } & Yes & 151 & 67.6 \\
\hline & No & 73 & 32.4 \\
\hline \multirow[t]{2}{*}{ Diabetes } & Yes & 63 & 28.0 \\
\hline & No & 157 & 71.0 \\
\hline \multirow[t]{2}{*}{ Hypertension } & Yes & 165 & 73.3 \\
\hline & No & 60 & 26.7 .0 \\
\hline \multirow[t]{2}{*}{ Smoking status (current) } & Yes & 85 & 37.8 \\
\hline & No & 140 & 62.2 \\
\hline
\end{tabular}

${ }^{*}$ City >100,000 inhabitants; Town $\leqslant 100,000$ inhabitants; CAD — coronary artery disease; MI - myocardial infarction; PTCA — percutaneous transluminal coronary angioplasty; CABG — coronary artery by-pass graft 
Table 2. RHD MIS Proportion of patients with low, medium and high scores in individual subscales

\begin{tabular}{lcccccc}
\hline Subscale & \multicolumn{2}{c}{ Low level } & \multicolumn{2}{c}{ Medium level } & \multicolumn{2}{c}{ High level } \\
\cline { 2 - 7 } & $\mathbf{N}$ & $\%$ & $\mathbf{N}$ & $\%$ & $\mathbf{N}$ & $\%$ \\
\hline Subjective knowledge & 57 & 25,33 & 58 & 25,78 & 110 & 48,89 \\
Objective knowledge & 59 & 26,22 & 113 & 50,22 & 53 & 23,56 \\
Expectations & 59 & 26,22 & 108 & 48,00 & 58 & 25,78 \\
Overall score & 63 & 28,00 & 88 & 39,11 & 74 & 32,89 \\
\hline
\end{tabular}

\section{Results}

\section{The level of readiness for discharge}

The assessment of readiness for discharge based on the RHD-MIS gave a mean result of $50.93 \pm 1.11$ points, which is in the range of mean results, similarly to the results of the assessment in individual subscales; subjective knowledge: $17.74 \pm 3.32$ points, objective knowledge: $15.62 \pm 3.42$ points, expectations: $17.57 \pm 6.93$ points. (Tab. 2).

\section{$\mathrm{RHD}$ MIS readiness for discharge and adherence}

The analysis of the implementation of the therapeutic plan defined as adherence in terms of pharmacotherapy depending on the results achieved in RHD MIS did not give unequivocal results both in terms of the overall result and the results in individual subsections (Tab. 3). This applies to individual drug groups tested separately and to all groups together. Significant differences noted in individual quarters for individual drugs may, contrary to expectations, suggest worse adherence in patients who were better prepared for discharge from hospital

\section{Adherence $\geq 80 \%$ a RHD MIS}

The results using the good adherence cut-off of $\geq 80 \%$ substantially support the results of the analysis where adherence was treated as a continuous variable. Paradoxically, patients characterized by a better readiness to discharge consistently worse implemented the therapeutic plan (Tab. 4).

\section{Patient opinions in relation to adherence}

Despite the disproportion in the distribution of responses, there were significant differences in adherence with regard to the opinion A (Is your illness serious?). Patients who think that their disease is not serious have significantly lower adherence to $\mathrm{P} 2 \mathrm{Y} 12$ receptor inhibitor in Q1 (28 $\pm 27 \%$ vs $72 \pm 38 \%, p=0.0473$ ) and statins in Q1 (36 $\pm 41 \%$ vs $76 \pm 33 \% p=0.0242)$ and in the annual analysis $(23 \pm 18 \%$ vs $65 \pm 32 \% p=0.0141)$.
No significant differences were noticed depending on the responses to B's opinion (Do you think that despite the medication, you need to change your lifestyle to prevent illness recurrance?) as well as to the opinion $\mathrm{C}$ (Do you think that systematic medication reduces the risk of reinfarction?) Patients who declare that they can count on the help of their family or relatives in complying with therapeutic recommendations (opinion D) had lower adherence to $\mathrm{P} 2 \mathrm{Y} 12$ receptor inhibilitor during one-year follow-up (60 $\pm 34 \%$ vs $74 \pm 30 \% p=0,0266)$. Patient declarations of opinions $E$ (Do you think your return home is associated with additional hazards?) showed no relation with adherence.

\section{RHD MIS in relation to average time of interruptions in therapy}

The patients with a high expectation score compared to the rest of the follow-up population had significantly longer mean treatment interruptions only for the P2Y12 receptor inhibitor $(p=0.0126)$ (Tab. 5).

\section{Discussion}

Non-adherence to medical recommendations, especially those concerning the use of drugs, is considered a significant problem in patients after myocardial infarction. The non-adherence to treatment is associated with increased incidence of adverse clinical events as well as treatment costs [6, 18-23]. According to the data presented by Naderi et al., adherence of patients diagnosed with coronary artery disease during two years of follow-up is only $50-66 \%$ [6].

Assessing the patient's readiness to leave hospital can be helpful for identifying patients who require additional interventions from healthcare professionals to continue therapy at home. Covering the patient with effective education reduces the number of complications, rehospitalization, and significantly improves the patient's quality of life and sense of security [24-27]. The knowledge regarding disease itself, treatment methods, possible complications and lifestyle modifications is indispensable for good functioning in the chronic 


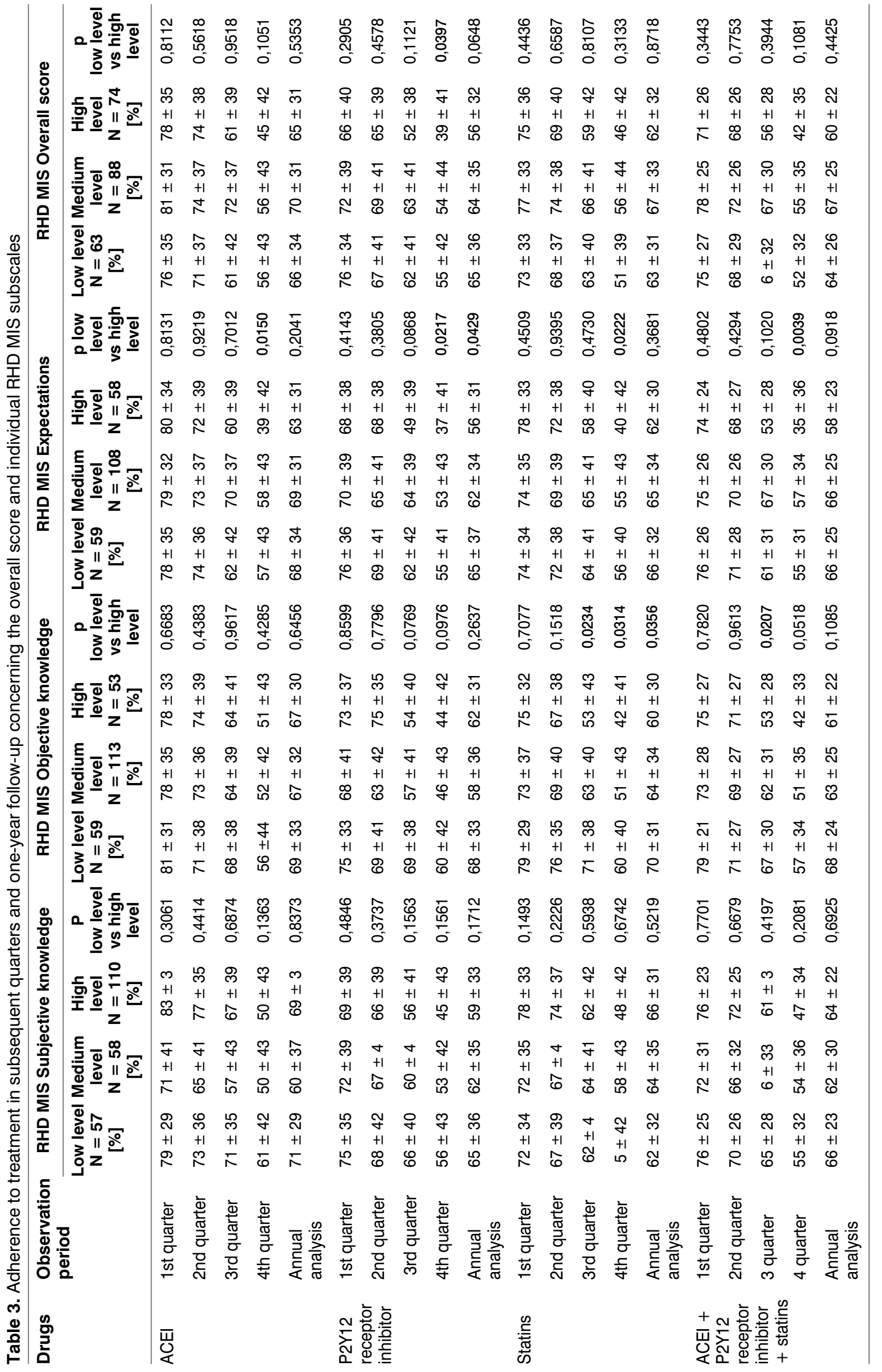




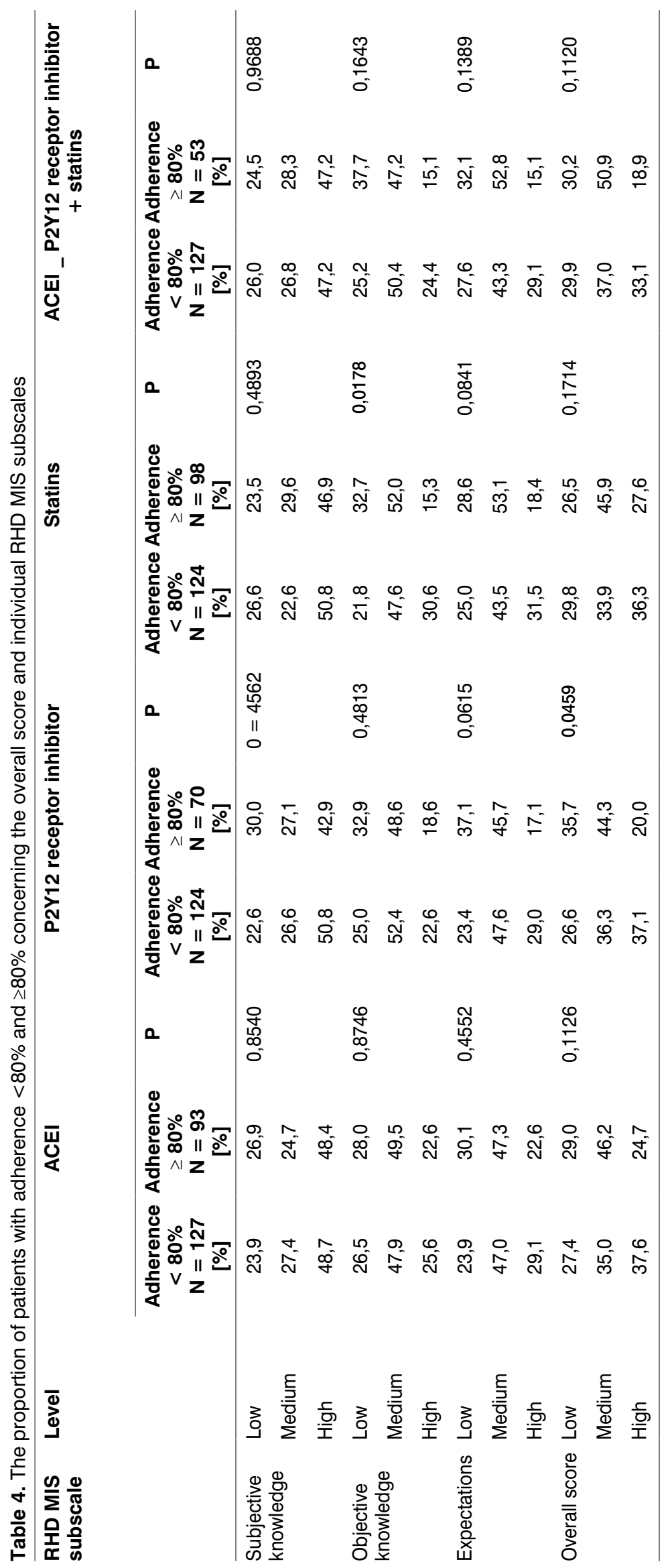


Table 5. The average duration of treatment interruptions concerning overall score and individual RHD MIS subscales

\begin{tabular}{|c|c|c|c|c|c|c|c|c|c|}
\hline $\begin{array}{l}\text { RHD MIS } \\
\text { subscale }\end{array}$ & Level & $\begin{array}{c}\text { ACEI } \\
\text { [days] }\end{array}$ & $\mathbf{p}$ & $\begin{array}{c}\text { P2Y12 } \\
\text { receptor } \\
\text { inhibitor } \\
\text { [days] }\end{array}$ & $\mathbf{p}$ & $\begin{array}{l}\text { Statins } \\
\text { [days] }\end{array}$ & $\mathbf{p}$ & $\begin{array}{c}\text { ACEI_P2Y12 } \\
\text { receptor } \\
\text { inhibitor } \\
\text { + statins } \\
\text { [days] }\end{array}$ & p \\
\hline \multirow{3}{*}{$\begin{array}{l}\text { Subjective } \\
\text { knowledge }\end{array}$} & Low & $37,46 \pm 37,45$ & 0,5193 & $36,49 \pm 44,44$ & 0,7853 & $79,36 \pm 86,42$ & 0,6278 & $16,00 \pm 23,39$ & 0,4528 \\
\hline & Medium & $50,23 \pm 54,94$ & & $41,53 \pm 54,62$ & & $71,19 \pm 85,24$ & & $3,00 \pm 0,00$ & \\
\hline & High & $41,30 \pm 55,43$ & & $42,32 \pm 46,38$ & & $67,25 \pm 54,44$ & & $19,77 \pm 16,90$ & \\
\hline \multirow{3}{*}{$\begin{array}{l}\text { Objective } \\
\text { knowledge }\end{array}$} & Low & $37,00 \pm 40,10$ & 0,8670 & $47,39 \pm 68,14$ & 0,3754 & $64,16 \pm 65,79$ & 0,2676 & $9,50 \pm 9,19$ & 0,6711 \\
\hline & Medium & $44,13 \pm 58,22$ & & $34,43 \pm 32,12$ & & $69,33 \pm 72,87$ & & $21,38 \pm 20,90$ & \\
\hline & High & $43,08 \pm 44,00$ & & $46,66 \pm 45,74$ & & $82,52 \pm 76,07$ & & $13,00 \pm 9,84$ & \\
\hline \multirow[t]{3}{*}{ Expectations } & Low & $53,46 \pm 53,68$ & 0,1468 & $23,60 \pm 22,16$ & 0,0126 & $71,49 \pm 74,21$ & 0,0593 & $16,00 \pm 0,00$ & 0,6836 \\
\hline & Medium & $34,31 \pm 37,54$ & & $42,87 \pm 48,11$ & & $68,81 \pm 81,10$ & & $14,85 \pm 16,26$ & \\
\hline & High & $43,82 \pm 63,97$ & & $53,44 \pm 61,02$ & & $75,72 \pm 51,04$ & & $21,80 \pm 21,87$ & \\
\hline \multirow[t]{3}{*}{ Overall score } & Low & $52,96 \pm 53,56$ & 0,2461 & $27,83 \pm 27,74$ & 0,0817 & $75,83 \pm 80,05$ & 0,0531 & $20,66 \pm 20,40$ & 0,2299 \\
\hline & Medium & $33,72 \pm 38,88$ & & $48,17 \pm 65,89$ & & $70,57 \pm 79,90$ & & $8,33 \pm 7,09$ & \\
\hline & High & $41,83 \pm 57,93$ & & $43,65 \pm 36,71$ & & $68,05 \pm 51,98$ & & $20,28 \pm 19,89$ & \\
\hline
\end{tabular}

phase of illness [7, 28]. Preparation for discharge, including education in the field of secondary prevention after a myocardial infarction, is a current standard of care. Nevertheless, the actions taken by medical professionals do not always respond to the patient's expectations [25, 29]. Weiss et al. Noticed a relationship between the low level of readiness for discharge declared by the patient and the subsequent difficulties in implementing therapeutic recommendations in the home environment [30].

To the best of our knowledge, this publication is the first such detailed analysis of the relationship between the readiness for discharge patients after myocardial infarction and the implementation of the therapeutic plan. Our observations did not show any clear relationships between the adherence to treatment with three basic groups of drugs and readiness to discharge from the hospital, assessed with the RHD MIS, both in terms of the overall score and the results of subscales. However, significant differences observed in some subscales with regard to individual drugs may, contrary to our expectations, suggest a worse implementation of the therapeutic plan in patients with higher knowledge (in relation to statins) or with lower needs for additional information (in relation to all drug groups in last quarter of follow-up). These suprising results require further indepth research to explain this phenomenon. According to the previously published studies [24, 27, 30], better adherence to treatment should be expect in patients with a higher level of readiness for discharge. However, the extensive, multi-faceted assessment of readiness for discharge that we used may reveal relations that were elusive with the use of other tools. Undoubtedly, our results clearly confirm that patient education should continue after discharge from the hospital [10, 32-37].

It is worth noting the differences between subjective and objective assessment of the patient's knowledge observed with RHD MIS. As many as 110 patients were satisfied with the level of their knowledge, while only 53 patients obtained a high score in the objective assessment of knowledge. Similarly, Weiss et al. [24] noticed a discrepancy in the assessment of readiness for discharge as judged by staff and patients. The low level of readiness for discharge observed by the nurse was associated with higher risk of complications and rehospitalization as compared with the patient's self-assessment [24]. Other studies have shown that patients' assessment of treatment priorities and cardiac rehabilitation may significantly differ from the healthcare professionals' opinion [38, 39]. Moreover, patients' beliefs regarding the disease also often differ from the rational assessment of specialists. This is crucial for the effectiveness of the therapy, because it is the patients' point of view that determines the way of coping with the disease, recovery expectations, reactions to subsequent symptoms of the disease, adherence to recommendations and commitment to rehabilitation [40, 41].

Of note, patients with a high score in terms of expectations (those, who declare not to expect additional information) had significantly worse adherence than patients with a low level in this subscale (declaring a willingness to expand their knowledge). Furthermore, 
consistently with previous report, subjects who were not aware of the seriousness of the disease had lower adherence to treatment with P2Y12 receptor inhibitor [42]. The awareness of receiving support from the family was associated with lower adherence to treatment with $\mathrm{P} 2 \mathrm{Y} 12$ receptor inhibitor. This finding is difficult to interpret, especially in view of reports suggesting that emotional family support as well as reminding medicine intake may help patients to implement their treatment plan [43-45].

In line with our observations, other reports also indicate the third and fourth quarters of treatment after myocardial infarction as the moment of adherence deterioration [6, 18, 37, 46-50]. The previously published studies identifying non-adherence determinants, did not include into account the readiness for discharge from the hospital [6, 18, 37, 46-54]. Further research is needed to explain the reasons for lower adherence in patients with higher RHD MIS scores, even if it only concerns some aspects of the assessment.

A limitation of this study is the fact that patients who received medications non-reimbursed by the National Health Fund were excluded from the analysis. Moreover, we do not have patients reports concerning the reasons for therapy discontinuation. On the other hand though, the strength of this study is its comprehensiveness of readiness for discharge from the hospital assessment and homogeneity of the study population.

\section{Conclusions}

The readiness for discharge from the hospital assessed with the RHD-MIS does not clearly affect the implementation of the therapeutic plan in the longterm follow-up in patients after myocardial infarction. Data suggesting a negative impact of some aspects of readiness for discharge on adherence to treatment require further, in-depth research.

\section{References:}

1. Nichols M, Townsend N, Scarborough P, et al. Cardiovascular disease in Europe: epidemiological update. Eur Heart J. 2013; 34(39): 3028-3034, doi: 10.1093/eurheartj/eht356, indexed in Pubmed: 24014390.

2. Rasmussen JN, Chong A, Alter DA. Relationship between adherence to evidence-based pharmacotherapy and long-term mortality after acute myocardial infarction. JAMA. 2007; 297(2): 177-186, doi: 10.1001/jama.297.2.177, indexed in Pubmed: 17213401.

3. Kubica A, Grześk G, Sinkiewicz W, et al. Compliance, concordance, adherence w przewlekłej terapii. Folia Cardiologica Excerpta. 2010; 5(2): 54-57.

4. Menzin J, Wygant $\mathrm{G}$, Hauch $\mathrm{O}$, et al. One-year costs of ischemic heart disease among patients with acute coronary syndromes: findings from a multi-employer claims database. Curr Med Res Opin. 2008; 24(2): 461-468, doi: 10.1185/030079908x261096, indexed in Pubmed: 18194592.

5. Simoni-Wastila L, Wei YJ, Qian J, et al. Association of chronic obstructive pulmonary disease maintenance medication adherence with all-cause hospitalization and spending in a Medicare population. Am
J Geriatr Pharmacother. 2012; 10(3): 201-210, doi: 10.1016/j.amjopharm.2012.04.002, indexed in Pubmed: 22521808

6. Naderi SH, Bestwick JP, Wald DS. Adherence to drugs that prevent cardiovascular disease: meta-analysis on 376,162 patients. Am J Med. 2012; 125(9): 882-887.e1, doi: 10.1016/j.amjmed.2011.12.013, indexed in Pubmed: 22748400

7. Kubica A. Edukacja zdrowotna na tle wybranych czynników a skuteczność terapii antyagregacyjnej u pacjentów po zawale serca. Wyd. Nauk. Uniwersytetu Mikołaja Kopernika,Toruń- Bydgoszcz . 2012.

8. Kubica A, Grześk G, Grąbczewska Z. Choroby układu sercowonaczyniowego- wyzwanie dla promocji zdrowia. Cardiovasc Forum. 2006; 11: 44-47.

9. Brunton SA. Improving medication adherence in chronic disease management. J Fam Pract. 2011; 60(4 Suppl Improving): S1-S8, indexed in Pubmed: 21472145.

10. Visser A, Deccache A, Bensing J. Patient education in Europe: united differences. Patient Education and Counseling. 2001; 44(1): 1-5, doi: 10.1016/s0738-3991(01)00111-2.

11. Kosobucka A, Michalski P, Pietrzykowski $\measuredangle$, et al. Adherence to treatment assessed with the Adherence in Chronic Diseases Scale in patients after myocardial infarction. Patient Prefer Adherence. 2018; 12: 333-340, doi: 10.2147/PPA.S150435, indexed in Pubmed: 29551891.

12. Kosobucka A, Kasprzak M, Michalski P, et al. Relation of the Readiness for Hospital Discharge after Myocardial Infarction Scale to socio-demographic and clinical factors. An observational study. Medical Research Journal. 2018; 3(1): 32-37, doi: 10.5603/mrj.2018.0006.

13. Kosobucka A, Michalski P, Pietrzykowski $\nvdash$, et al. The impact of readiness to discharge from hospital on adherence to treatment in patients after myocardial infarction. Cardiol J. 2020 [Epub ahead of print], doi: 10.5603/CJ.a2020.0005, indexed in Pubmed: 32037501.

14. Pietrzykowski Ł, Michalski P, Kosobucka A, et al. Medication adherence and its determinants in patients after myocardial infarction. Sci Rep. 2020; 10(1): 12028, doi: 10.1038/s41598-020-68915-1, indexed in Pubmed: 32694522

15. Buszko K, Kosobucka A, Michalski P, et al. The readiness for hospital discharge of patients after acute myocardial infarction: a new self-reported questionnaire. Medical Research Journal. 2017; 2(1): 20-28, doi: 10.5603/mrj.2017.0004.

16. Ho PM, Lambert-Kerzner A, Carey EP, et al. Multifaceted intervention to improve medication adherence and secondary prevention measures after acute coronary syndrome hospital discharge: a randomized clinical trial. JAMA Intern Med. 2014; 174(2): 186-193, doi: 10.1001/jamainternmed.2013.12944, indexed in Pubmed: 24247275.

17. Bansilal S, Castellano JM, Garrido E, et al. Assessing the Impact of Medication Adherence on Long-Term Cardiovascular Outcomes. J Am Coll Cardiol. 2016; 68(8): 789-801, doi: 10.1016/j.jacc.2016.06.005, indexed in Pubmed: 27539170.

18. Ho PM, Spertus JA, Masoudi FA, et al. Impact of medication therapy discontinuation on mortality after myocardial infarction. Arch Intern Med. 2006; 166(17): 1842-1847, doi: 10.1001/archinte.166.17.1842, indexed in Pubmed: 17000940

19. Simpson RJ. Challenges for improving medication adherence. JAMA 2006; 296(21): 2614-2616, doi: 10.1001/jama.296.21.jed60074, indexed in Pubmed: 17101641

20. Hussain S, Jamal SZ, Qadir F. Medication Adherence In Post Myocardial Infarction Patients. J Ayub Med Coll Abbottabad. 2018; 30(4): 552-557, indexed in Pubmed: 30632336.

21. Lee YM, Kim RB, Lee HJ, et al. Relationships among medication adherence, lifestyle modification, and health-related quality of life in patients with acute myocardial infarction: a cross-sectional study. Health Qual Life Outcomes. 2018; 16(1): 100, doi: 10.1186/s12955-018-0921-z, indexed in Pubmed: 29788961.

22. Kubica A, Obońska K, Kasprzak M, et al. Prediction of high risk of non-adherence to antiplatelet treatment. Kardiol Pol. 2016; 74(1) 61-67, doi: 10.5603/KP.a2015.0117, indexed in Pubmed: 26101025

23. Spertus JA, Kettelkamp R, Vance C, et al. Prevalence, predictors, and outcomes of premature discontinuation of thienopyridine therapy after drug-eluting stent placement: results from the PREMIER registry. Circulation. 2006; 113(24): 2803-2809, doi: 10.1161/CIRCULATIONAHA.106.618066, indexed in Pubmed: 16769908.

24. Weiss ME, Costa LL, Yakusheva O, et al. Validation of patient and nurse short forms of the Readiness for Hospital Discharge Scale and their relationship to return to the hospital. Health Serv Res. 2014; 49(1): 304-317, doi: 10.1111/1475-6773.12092, indexed in Pubmed 23855675

25. Weiss ME, Piacentine LB, Lokken L, et al. Perceived readiness for hospital discharge in adult medical-surgical patients. Clin Nurse Spec. 2007; 21(1): 31-42, doi: 10.1097/00002800-200701000-00008, indexed in Pubmed: 17213738. 
26. Michalski P, Kosobucka A, Pietrzykowski $Ł$, et al. Knowledge and learning preferences of patients with myocardial infarction. Medical Research Journal. 2017; 1(4): 120-124, doi: 10.5603/mrj.2016.0022.

27. Kubica A, Kochman W, Bogdan M, et al. The influence of undergone pecutaneous coronary interventions and earlier hospitalization with myocardial infarction on the level of knowledge and the effectiveness of health education in patients with myocardial infarction. Advances in Interventional Cardiology. 2009; 5: 25-30

28. Kubica A, Grześk G, Grąbczewska Z. Choroby układu sercowonaczyniowego- wyzwanie dla promocji zdrowia. Cardiovasc Forum. 2006; 11: 44-47.

29. Paterson B, Kieloch B, Gmiterek J. ,They never told us anything': postdischarge instruction for families of persons with brain injuries. Rehabil Nurs. 2001; 26(2): 48-53, doi: 10.1002/j.2048-7940.2001.tb01925.x indexed in Pubmed: 12035699

30. Weiss ME, Yakusheva O, Bobay KL. Quality and cost analysis of nurse staffing, discharge preparation, and postdischarge utilization. Health Serv Res. 2011; 46(5): 1473-1494, doi: 10.1111/j.1475-6773.2011.01267.x, indexed in Pubmed: 21517836.

31. Stewart K, Mc Namara KP, George J. Challenges in measuring medication adherence: experiences from a controlled trial. Int J Clin Pharm. 2014; 36(1): 15-19, doi: 10.1007/s11096-013-9877-6, indexed in Pubmed: 24293282.

32. Farmer KC. Methods for measuring and monitoring medication regimen adherence in clinical trials and clinical practice. Clin Ther. 1999 21(6): 1074-90; discussion 1073, doi: 10.1016/S0149-2918(99)800265, indexed in Pubmed: 10440628

33. Gierlotka M, Zdrojewski T, Wojtyniak B, et al. Incidence, treatment, in-hospital mortality and one-year outcomes of acute myocardia infarction in Poland in 2009-2012--nationwide AMI-PL database. Kardiol Pol. 2015; 73(3): 142-158, doi: 10.5603/KP.a2014.0213, indexed in Pubmed: 25371307.

34. Kubica A, Sinkiewicz W, Szymański P, et al. Edukacja zdrowotna w chorobach układu krażenia — możliwości i zagrożenia. Folia Cardiol Excerpta. 2006; 2: 177-181.

35. . A, Jafar S, Kumar G, et al. Cardiac Risk Factor Changes Through an Intensive Multifactorial Life Style Modification Program in CHD Patients: Results from a Two Year Follow Up. Journal of Biological Sciences. 2008; 8(2): 248-257, doi: 10.3923/jbs.2008.248.257.

36. Kubica A, Pufal J, Moczulska B, et al. Skuteczność edukacji zdrowot-nej u osób hospitalizowanych w klinice kardiologii. Psychiatr Prak Ogólnolek. 2005; 5: 61-68.

37. Kubica A, Kasprzak M, Obońska K, et al. Impact of health education on adherence to clopidogrel and clinical effectiveness of antiplatele treatment in patients after myocardial infarction. Medical Research Journal. 2016; 3(4): 154-159, doi: 10.5603/fmc.2015.0010.

38. Normington K, Goodwin S. A personalised approach to cardiac rehabilitation. Prof Nurse. 2000; 15(7): 432-436, indexed in Pubmed: 11129924

39. Kubica A Kasprzak M, Obońska K, et al. Discrepancies in assessment of adherence to antiplatelet treatment after myocardial infarction. Pharmacology. 2015; 95(1-2): 50-58, doi: 10.1159/000371392, indexed in Pubmed: 25592409.

40. Gassner LA, Dunn S, Piller N. Patients' interpretation of the symptoms of myocardial infarction: implications for cardiac rehabilitation Intensive Crit Care Nurs. 2002; 18(6): 342-354, doi: 10.1016/s09643397(02)00072-1, indexed in Pubmed: 12526872.
41. Smith J, Liles C. Information needs before hospital discharge of myocardial infarction patients: a comparative, descriptive study. J Clin Nurs. 2007; 16(4): 662-671, doi: 10.1111/j.1365-2702.2006.01689.x, indexed in Pubmed: 17402947

42. Wiles R, Kinmonth A. Patients' understandings of heart attack: implications for prevention of recurrence. Patient Educ Couns. 2001; 44(2): 161-169, doi: 10.1016/s0738-3991(00)00187-7, indexed in Pubmed: 11479056

43. Crowley MJ, Zullig LL, Shah BR, et al. Medication non-adherence after myocardial infarction: an exploration of modifying factors. J Gen Intern Med. 2015; 30(1): 83-90, doi: 10.1007/s11606-014-3072-x, indexed in Pubmed: 25361685

44. Fivecoat HC, Sayers SL, Riegel B, et al. Social support and self-care of patients with heart failure. Ann Behav Med. 2008; 35(1): 70-79, doi: 10.1007/s12160-007-9003-x, indexed in Pubmed: 18347906

45. Wu JR, Chung M, Lennie TA, et al. Testing the psychometric properties of the Medication Adherence Scale in patients with heart failure. Heart ung. 2008; 37(5): 334-343, doi: 10.1016/j.hrtlng.2007.10.001, indexed in Pubmed: 18790334

46. Suzuki T, Shiga T, Omori H, et al. Adherence to medication and characteristics of Japanese patients with non-valvular atrial fibrillation. J Cardiol. 2017; 70(3): 238-243, doi: 10.1016/j.jjcc.2016.11.009, indexed in Pubmed: 28007412

47. Winter MP von Lewinski $D$, Wallner $M$, et al Incidence, predictors, and prognosis of premature discontinuation or switch of prasugrel or ticagrelor: the ATLANTIS - SWITCH study. Sci Rep. 2019; 9(1): 8194, doi: 10.1038/s41598-019-44673-7, indexed in Pubmed: 31160687.

48. Ko DT, Chiu M, Guo H, et al. Patterns of use of thienopyridine therapy after percutaneous coronary interventions with drug-eluting stents and bare-metal stents. Am Heart J. 2009; 158(4): 592-598.e1, doi: 10.1016/j.ahj.2009.06.030, indexed in Pubmed: 19781419

49. Michalski P, Kosobucka A, Pietrzykowski $\measuredangle$, et al. Effectiveness of therapeutic education in patients with myocardial infarction. Medical Research Journal. 2018; 2(3): 89-96, doi: 10.5603/mrj.2017.0011

50. Michalski P, Kasprzak M, Siedlaczek M, et al. The impact of knowledge and effectiveness of educational intervention on readiness for hospital discharge and adherence to therapeutic recommendations in patients with acute coronary syndrome. Medical Research Journal. 2020, doi: 10.5603/mri.a2020.0023

51. Pietrzykowski Ł, Michalski P, Kosobucka A, et al. Medication adherence and its determinants in patients after myocardial infarction. Sci Rep. 2020; 10(1): 12028, doi: 10.1038/s41598-020-68915-1, indexed in Pubmed: 32694522

52. Kubica A, Adamski P, Bączkowska A, et al. The rationale for Multilevel EDucational and MOtivational intervention in patients after myocardial infarcTION (MEDMOTION) project is to support multicentre randomized clinical trial EvaLuating safety and EffiCacy of two TicagRelor-based de-escalation Ant. Medical Research Journal. 2020, doi: 10.5603/mri.a2020.0043

53. Kubica A. Self-reported questionnaires for a comprehensive assessment of patients after acute coronary syndrome. Medical Research Journal. 2019; 4(2): 106-109, doi: 10.5603/mri.a2019.0021.

54. Kubica A, Gruchała M, Jaguszewski M, et al. Adherence to treatment - a pivotal issue in long-term treatment of patients with cardiovascular diseases. An expert standpoint. Medical Research Journal. 2018; 2(4): 123-127, doi: 10.5603/mri.2017.0016. 